\title{
Novel therapeutic approaches for treatment of COVID-19
}

\author{
Nikoo Hossein-khannazer ${ }^{1,2} \cdot$ Bahare Shokoohian $^{3,4} \cdot$ Anastasia Shpichka $^{5,6} \cdot$ Hamid Asadzadeh Aghdaei $^{7}$. \\ Peter Timashev ${ }^{5,6,8,9}$ (D) Massoud Vosough ${ }^{3}$
}

Received: 15 April 2020 /Revised: 11 May 2020 / Accepted: 19 May 2020/Published online: 3 June 2020

(C) Springer-Verlag GmbH Germany, part of Springer Nature 2020

\begin{abstract}
To date, there is no licensed treatment or approved vaccine to combat the coronavirus disease of 2019 (COVID-19), and the number of new cases and mortality multiplies every day. Therefore, it is essential to develop an effective treatment strategy to control the virus spread and prevent the disease. Here, we summarized the therapeutic approaches that are used to treat this infection. Although it seems that antiviral drugs are effective in improving clinical manifestation, there is no definite treatment protocol. Lymphocytopenia, excessive inflammation, and cytokine storm followed by acute respiratory distress syndrome are still unsolved issues causing the severity of this disease. Therefore, immune response modulation and inflammation management can be considered as an essential step. There is no doubt that more studies are required to clarify immunopathogenesis and immune response; however, new therapeutic approaches including mesenchymal stromal cell and immune cell therapy showed inspiring results.
\end{abstract}

Keywords COVID-19 Coronavirus $\cdot$ Therapeutic approaches $\cdot$ Severe acute respiratory syndrome $\cdot$ Acute respiratory distress syndrome $\cdot$ Cell therapy

\section{Introduction}

Corona viruses are a large family of enveloped, positive-sense RNA viruses that have the largest RNA genome (rage from 26 to $32 \mathrm{~kb}$ ) [1,2]. Several coronavirus epidemics such as Severe Acute Respiratory Syndrome Coronavirus (SARS-CoV) and Middle East Respiratory Syndrome Coronavirus (MERS$\mathrm{CoV}$ ) have occurred during the past years $[2,3]$. At the end

Peter Timashev

timashev.peter@gmail.com

Massoud Vosough

masvos@ royaninstitute.org

1 Department of Immunology, School of Medicine, Shahid Beheshti University of Medical Sciences, Tehran, Iran

2 Gastroenterology and Liver Diseases Research Center, Research Institute for Gastroenterology and Liver Diseases, Shahid Beheshti University of Medical Sciences, Tehran, Iran

3 Department of Regenerative Medicine, Cell Science Research Center, Royan Institute for Stem Cell Biology and Technology, ACECR, Tehran, Iran

4 Department of Medical Biotechnology, School of Advanced Technologies in Medicine, Tehran University of Medical Sciences, Tehran, Iran of 2019, a novel coronavirus infection named coronavirus disease of 2019 (COVID-19) was first identified in Wuhan, China [4-7]. Due to the fast transmission, it is reported in almost all countries and has become a global crisis. Therefore, COVID-19 pandemic becomes an international threat for human health and economy $[1,8]$.

COVID-19 spreads fast among people and the mortality rate is controversial; however, it was less than $2 \%$ in some

5 Institute for Regenerative Medicine, Sechenov University, Moscow, Russia

6 Chemistry Department, Lomonosov Moscow State University, Moscow, Russia

7 Department of Molecular Biology, Basic and Molecular Epidemiology of Gastrointestinal Disorders Research Center, Research Institute for Gastroenterology and Liver Diseases, Shahid Beheshti University of Medical Sciences, Tehran, Iran

8 Department of Polymers and Composites, NN Semenov Institute of Chemical Physics, Moscow, Russia

9 Institute of Photon Technologies, Federal Research Center Crystallography and Photonics RAS, Moscow, Russia 
studies. The main manifestations of the disease include fever, dry caught, headache, shortness of breath, pneumonia, acute respiratory distress syndrome (ARDS), septic shock, and even death $[3,11,12]$.

The genome sequencing of this virus revealed more than $82 \%$ identity to SARS-CoV [9]. Analysis indicated that the binding affinity of virus $\mathrm{S}$ protein to the angiotensinconverting enzyme 2 (ACE2) receptor on human alveolar epithelial cells is higher compared with the SARS-CoV [10].

Since SARS-CoV-2 is a new pathogen, little is known about it. Moreover, there is no licensed treatment or approved vaccine and the number of new cases and mortality multiplies daily [8]. Therefore, it is vital to develop an effective treatment strategy to control the virus spread and prevent the disease [1, $11]$.

\section{Immunopathogenesis of COVID-19}

Although the pathogenesis of this disease has not been fully understood, it seems that the host immune responses play an important role. Aberrant host immune response causes lung tissue damage, reduced lung capacity, and finally respiratory failure [4]. Studies indicated that dendritic cells (DCs) and macrophages are playing crucial role in innate immune responses $[12,13]$. These cells produce inflammatory cytokines and chemokines including TNF- $\alpha$, IL-12, IL-6, IFN $\gamma$, and IL8 , and monocyte chemoattractant protein (MCP-1), macrophage colony-stimulating factor (GM-CSF), and granulocyte-colony-stimulating factor (G-CSF) [6, 14]. These inflammatory responses may lead to systemic inflammation $[6,7,13,14]$.

Adoptive immunity plays a major role in viral infections [15]. Cytotoxic $\mathrm{T}$ cells (CD8+ $\mathrm{T}$ cells) are the main $\mathrm{T}$ cell subsets that destroy infected cells [16]. Therefore, the number of these cells is one of the major factors for clearance of the viral infection $[17,18]$. Preliminarily, it was indicated that the number of total $\mathrm{T}$ cells, CD4+ and CD8+ T cells, reduced significantly in COVID-19 patients. This decrease was more intensive in ICU admitted patients compared with that in nonICU admitted individuals [19]. It is also reported that $\mathrm{T}$ cell clonal exhaustion occurred during the infection and the expression of certain $\mathrm{T}$ cell surface markers like PD1 (programmed cell death protein 1) and TIM-3 (T cell immunoglobulin and mucin domain-containing molecule-3) markedly increased $[19,20]$. The cytokine storm occurred in response to SARS-CoV-2 infection that led to increased expression of NKG2A (natural-killer group 2, member A) on cytotoxic T cells (CTLs) and NK cells. This upregulation suppressed CTL and NK function and cytokine secretion [19, 21, 22]. It is suggested that inflammatory cytokines, TNF- $\alpha$ and IL-6, mainly originated from apoptotic monocytes $(\mathrm{CD} 14+\mathrm{CD} 16+$ ) and macrophages and induced T CD4+ and T CD8+ cells
$[19,23]$. These excessive inflammatory responses might result in respiratory system pathology and dysfunction [23].

Perhaps it takes many years to achieve a specific and effective therapeutic protocol, efficient vaccine, or suitable medicine for the treatment of COVID-19. There is a wide range of existing and current treatment strategies categorized into antiviral drugs, immunotherapy protocols including convalescent serum and monoclonal antibodies, cell-based therapies, hydroxychloroquine, Chinese medicine, and steroids (just for patients who suffer from ARDS) [24]. A schematic figure (Fig. 1) summarized the novel therapeutic approaches in treatment of COVID-19 patients. Moreover, there are a growing number of clinical trials registered for the treatment of COVID-19 (Table 1).

\section{Passive immunotherapy}

\section{Convalescent serum}

Antibody injection to the patients and susceptible people provides rapid immunity to treat or prevent the disease [25-27]. Past experiences from SARS and MERS viral infections indicated that passive immunotherapy could be a potential treatment strategy for the patients [27-29]. It is considered that passive immunotherapy could also be beneficial in SARSCoV-2 infection [30]. Extracting neutralizing antibodies from recovered individuals with high titer of antibodies in sera and transfusion to infected patient could deactivate the virus. However, neutralization activity of these antibodies is not fully understood. It has been showed that neutralizing antibodies are not long lasting and only the recently recovered patients are suitable candidates [31]. It has also been reported that the neutralizing antibody titers vary among the patients and elderly patients had higher antibody titer compared with young recovered individuals [32]. It is supposed that convalescent serum administration may induce phagocytosis and antibody-mediated cellular cytotoxicity [25, 27]. One important implications for using convalescent serum is the risk for antibody-dependent enhancement (ADE) [33]. It is supposed that these neutralizing antibodies may enhance other viral infections [34]. Another major limitation of this strategy is donor shortage. However, by increasing the number of recovered individuals, this limitation would be solved [25].

\section{Monoclonal antibodies}

It has been shown that monoclonal antibodies (mAbs) could be an effective tool for the treatment of viral infectious diseases [35-37]. Different techniques have been used to develop mAbs including phage display library, hybridoma, single B cell isolation, and transgenic mice [37]. Various monoclonal antibodies developed against MERS and SARS infections include m396, 80R, and S3.1 against SARS and LCA60 for the 


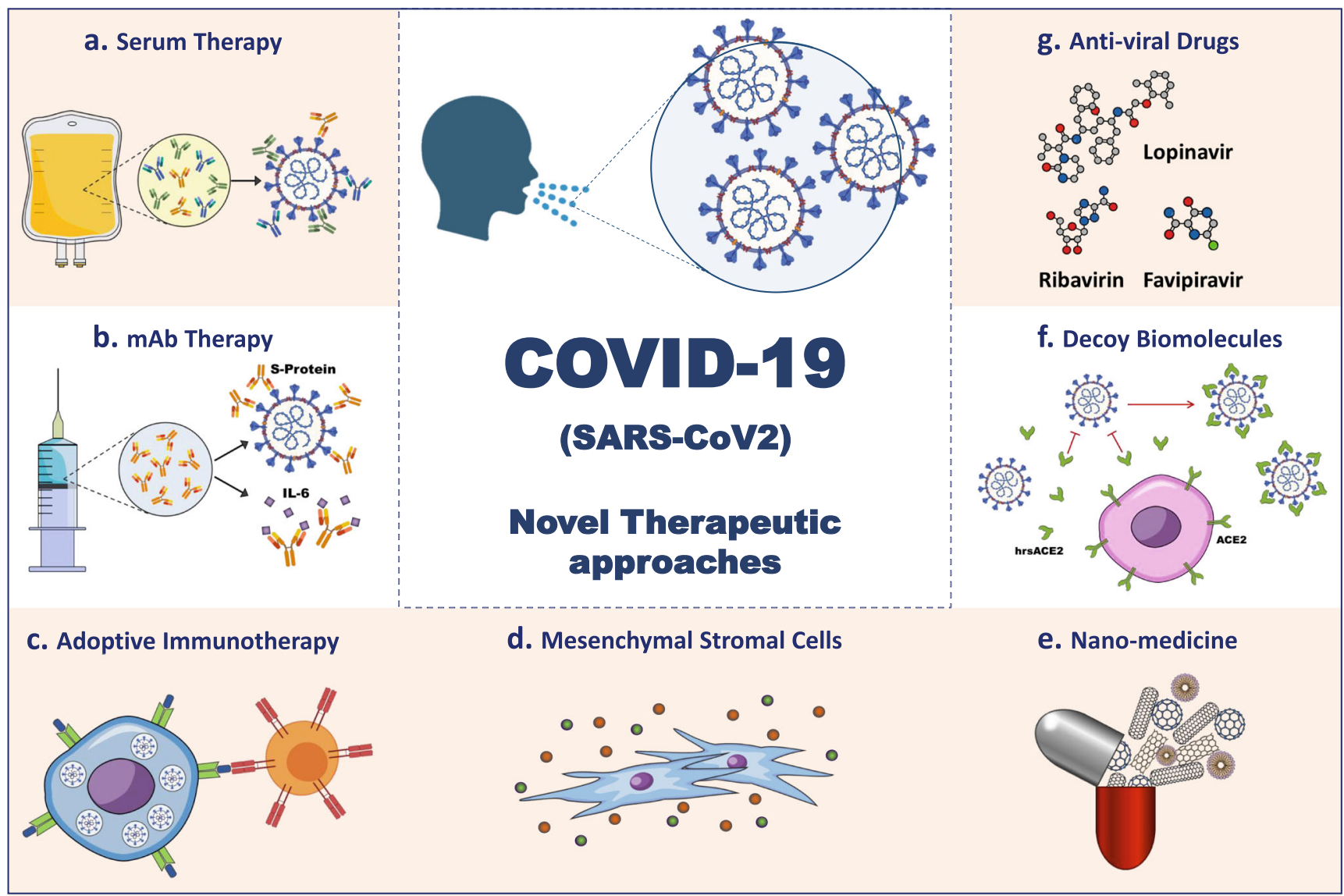

Fig. 1 Novel therapeutic strategies for treatment of clinical complications of COVID-19. (a) Passive immunotherapy using serum of immunized individuals. (b) Monoclonal antibodies can directly target virus particles. Also, mAbs can be used to eliminate crucial cytokines in progression of inflammation, e.g., IL-6. (c) The effector cells in adoptive immunotherapy can be used to specifically target infected cells and enhance anti-viral immune responses. (d) Mesenchymal stromal cells are key players in immunomodulation of severe immune response. The paracrine effect of these cells can tune down immune reaction. (e) Using nanostructures for drug delivery in different medical applications. (f) Recombinant ACE2 receptor protein in soluble form attaches to viral particles. (g) Antiviral medicines can prohibit viral proliferation treatment of MERS disease [29, 37-41]. These mAbs limited virus replication and facilitated lung recovery in animal models [42-44]. S protein is also the most immunogenic determinant of coronaviruses [40]. Several mAbs target receptor-binding domain (RBD) in the virus spike (S) glycoprotein and inhibit the virus to invade the host cell [9]. It is reported that mAbs against SARS-CoV-1 could cross react with SARS-CoV-2 [45]. It is indicated in the preprint that mAb $1 \mathrm{~A} 9$ that targets the $\mathrm{S}$ protein of SARS-CoV-1 could interact with SARS-CoV-2 [46].

Tocilizumab is a humanized monoclonal antibody against IL-6 receptor cytokine. Tocilizumab targets both membrane and soluble-bound IL- 6 receptors. This mAb is used for the treatment of COVID-19 patients [47]. It is shown that the IL-6 level is considerably high in severe COVID-19 cases. Treatment of 21 severe COVID-19 cases with tocilizumab indicated that using this monoclonal antibody is an effective treatment and well tolerated in these patients. In the preprinted study, tocilizumab caused body temperature and CRP returned to the normal levels and improved lung function
[48]. There are also many registered clinical trials on efficiency and safety of tocilizumab for the treatment of COVID-19 (Table 1).

VEGF is one of the main mediators of vascular permeability and progression of ARDS. Bevacizumab is a humanized monoclonal antibody that targets VEGF and employed in a phase II/III clinical trial for the treatment of COVID-19 patients (NCT04275414).

As described earlier, during the SARS-CoV-2 infection, exhaustion of $\mathrm{T}$ and NK cells happens. In order to restore these cells, using monoclonal antibodies to block the PD-1/ PD-L1 and TIM3 pathways may have beneficial therapeutic effects as well [49].

\section{Kinase inhibitors}

It is suggested that an inhibitor of Janus kinase (JAK) called baricitinib could prevent the entry of SARS-CoV-2 into the host cells and also inhibit the inflammation [50, 51]. Cyclin Gassociated kinase (GAK) and AP2-associated protein kinase 1 


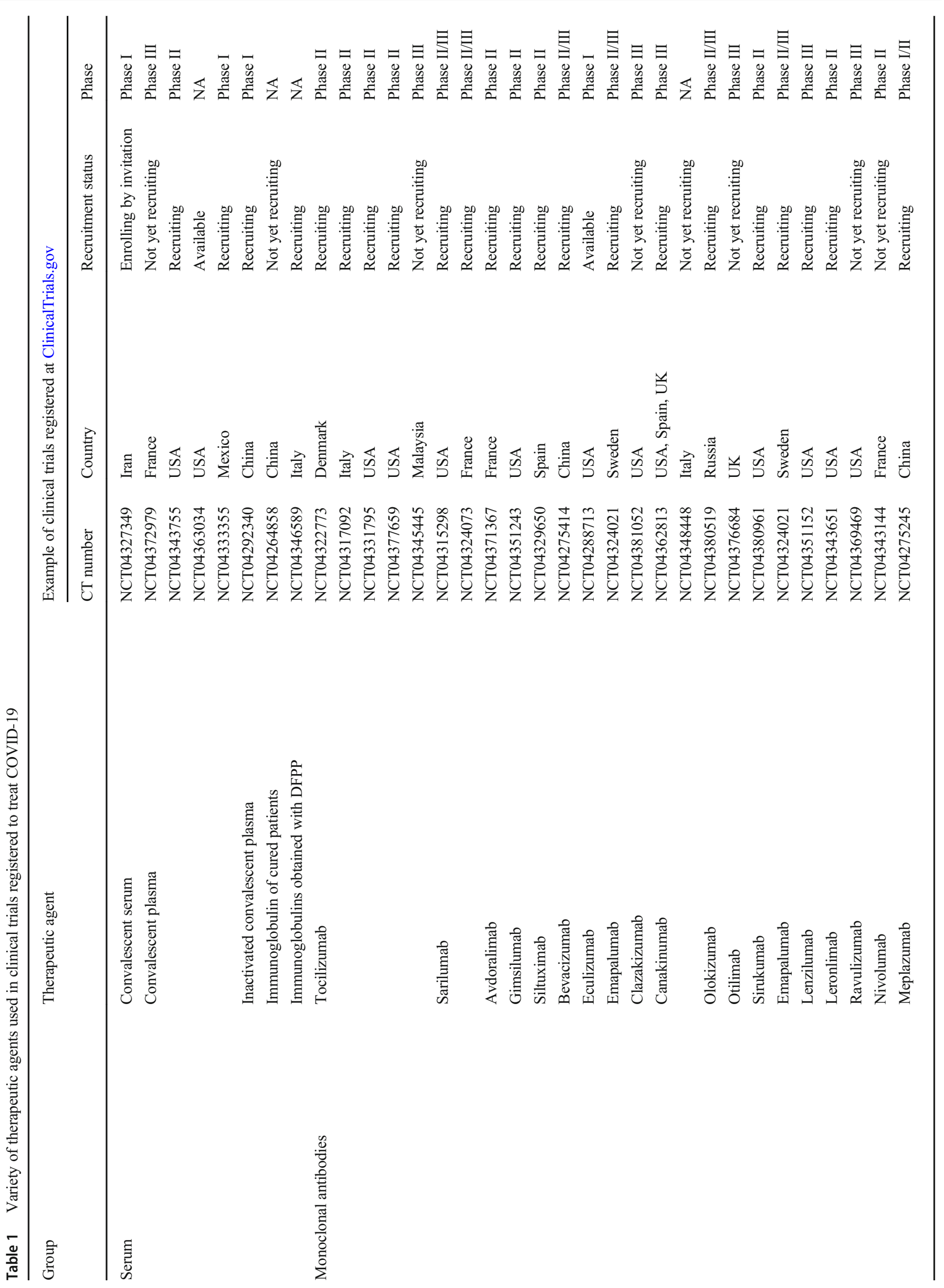




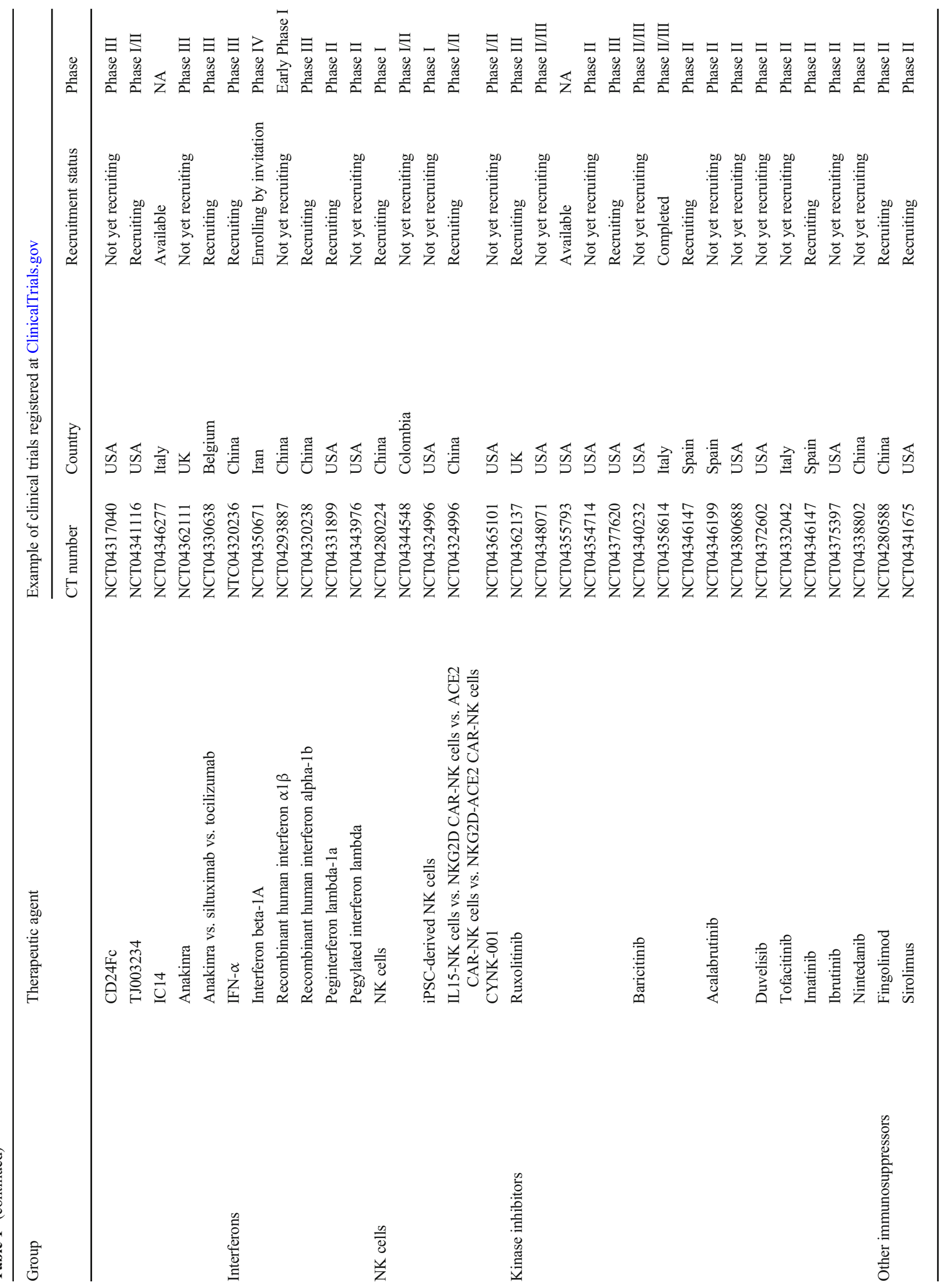




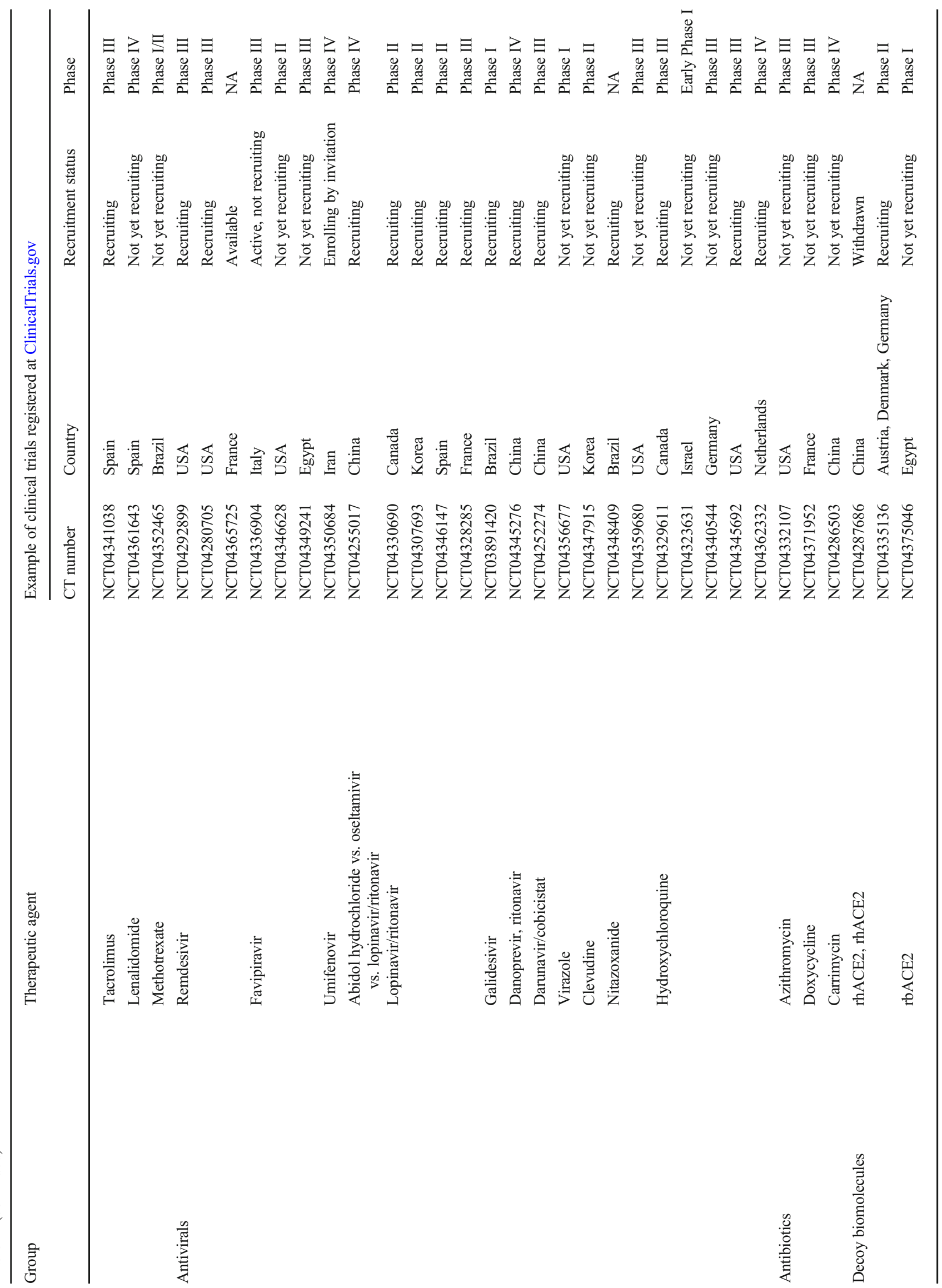



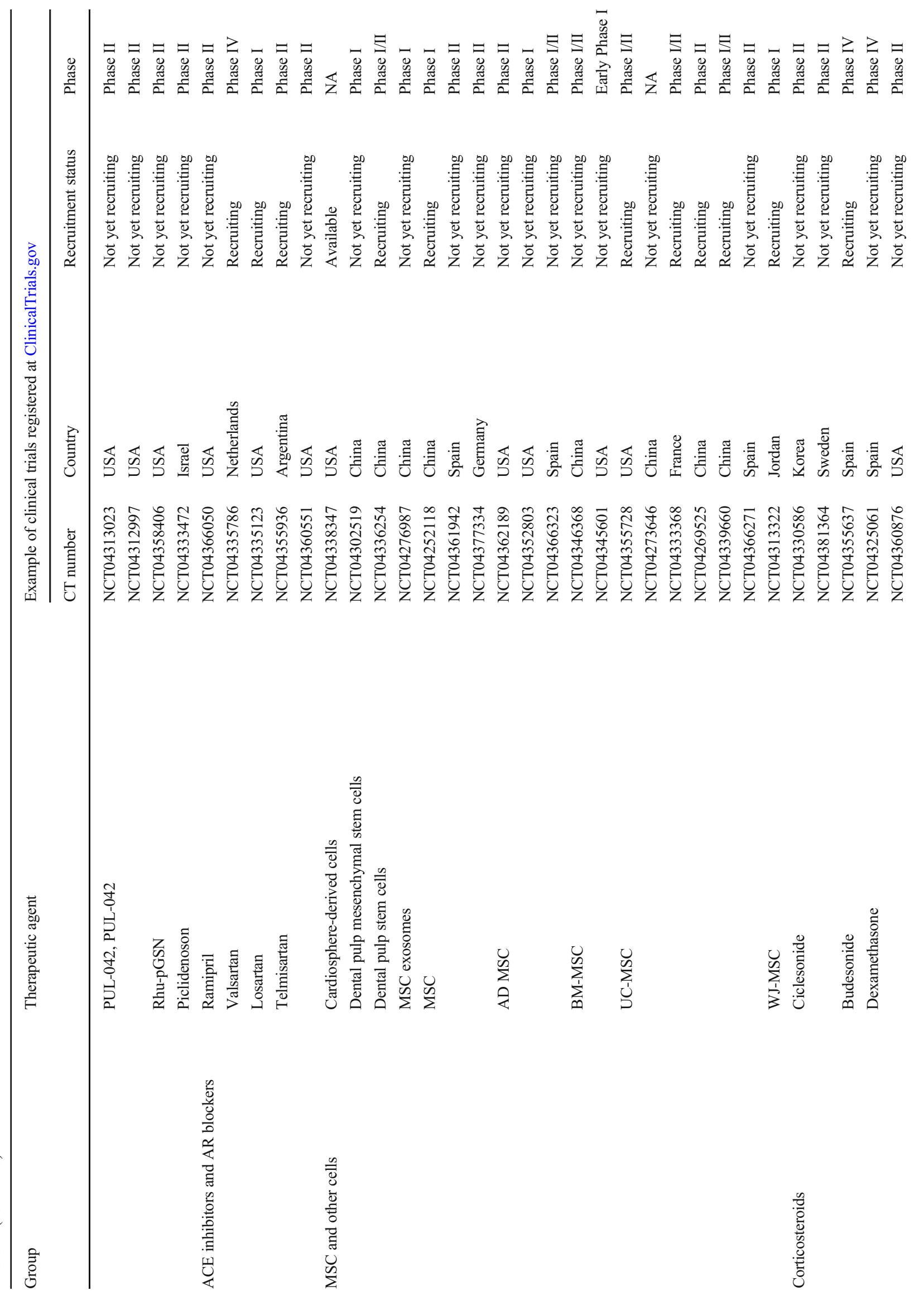


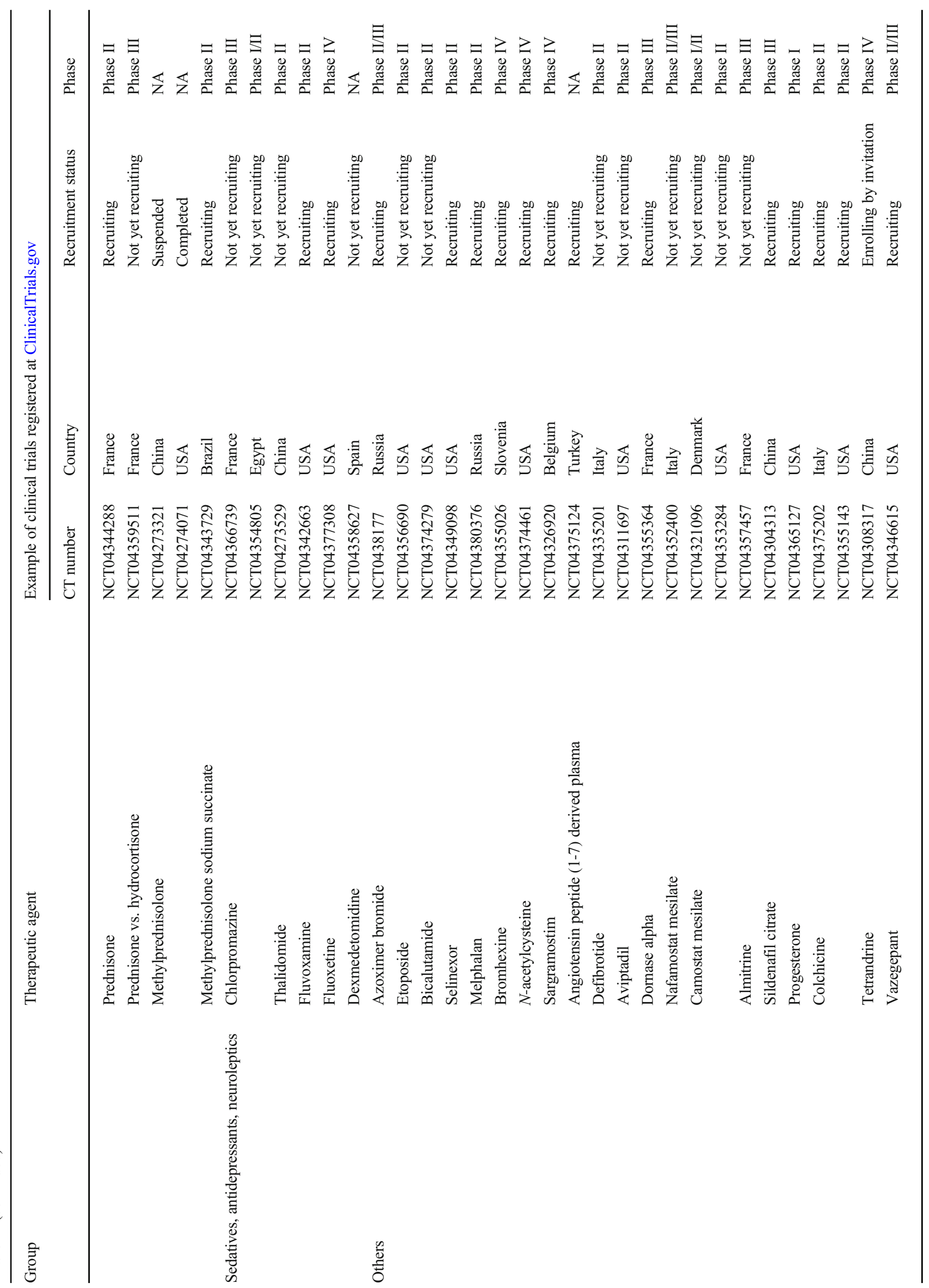




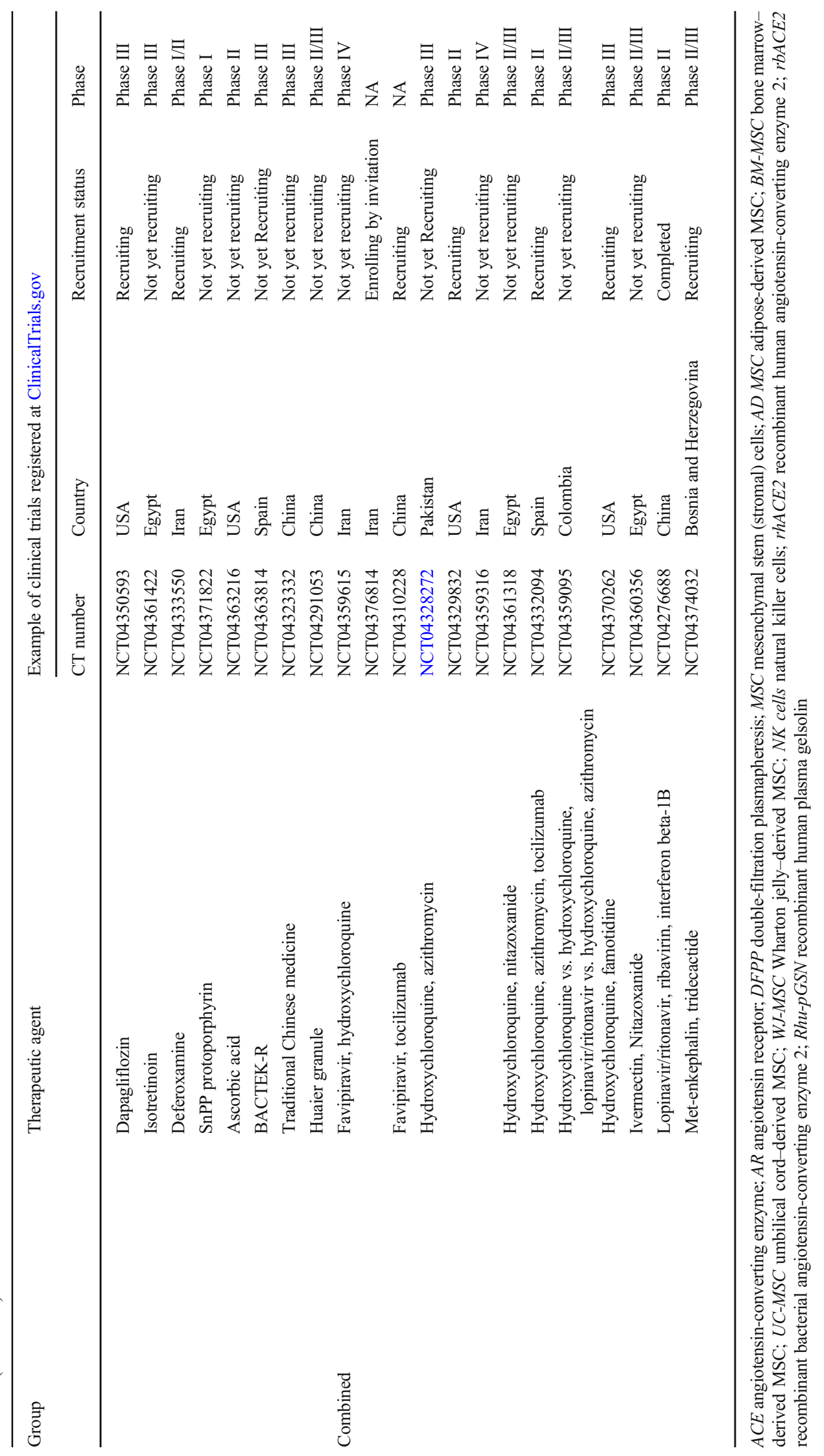


(AAK1) are endocytosis regulators. Baricitinib might inhibit SARS COV-2 entry by disruption of these regulators. Other JAK inhibitors such as fedratinib and ruxolitinib are also candidates for decreasing inflammatory cytokines in COVID-19 individuals [51]. Although JAK inhibitors have wide effects and can inhibit cytokine secretion such as IFN- $\alpha$, more studies need to confirm their safety and efficiency [14].

\section{Adoptive immunotherapy}

Adoptive transfer of antigen-specific $\mathrm{T}$ cells has been developed for the treatment of cancers, autoimmunity, and viral infections including hepatitis $\mathrm{B}$ virus (HBV), hepatitis $\mathrm{C}$ virus (HCV), and cytomegalovirus (CMV) [24-26]. In this approach, anti-viral-specific $\mathrm{T}$ cell clones are generated, expanded, and purified in vitro [26]. It is shown that engineered SARS-specific CD8+ T cells had normal activity and function and may be a potential therapeutic tool for SARS infection [27]. Recently, it has been indicated that the number of CD8+ $\mathrm{T}$ cells decreased dramatically and the ratio of $\mathrm{CD} 4+/ \mathrm{CD} 8+\mathrm{T}$ cells increased during the SARS-CoV-2 infection. This decrease in the number of CD8+ lymphocytes has been correlated with the disease severity and clinical outcome [52]. It has also indicated that $\mathrm{CD} 8+\mathrm{T}$ cells and the $\mathrm{CD} 4+/ \mathrm{CD} 8+$ ratio decreased and increased respectively after the treatment. It seems that CD8+ T cells play an important role in COVID19 and could be a potential biomarker of the disease [52, 53]. Due to these findings, adoptive transfer of COVID-19-specific CD8+ T cells may be an effective treatment strategy [28]. NK cells are innate immune cells that play a crucial role in host immune response after viral infections [54]. Preprinted studies indicated that NK cell population decreased remarkably during the disease $[55,56]$. It has been indicated that during SARS-CoV-2 infection, increased amount of IL-6 inflammatory cytokine had negative correlation with the number of NK cells [52]. Thus, it is assumed that adoptive transfer of NK cells may have an effective therapeutic approach. Therefore, recently, an ongoing phase I clinical trial has been registered in which NK cell therapy in combination with conventional therapies for COVID-19 patients was proposed (NCT04280224). Altogether, it seems that cell-mediated immunity plays an important role in host immune response against SARS-CoV-2 [57].

\section{Mesenchymal stromal cells}

Persistence of inflammatory cytokines in COVID-19 patients leads to lung dysfunction and even death. Using corticosteroids for dampening cytokine storm suppresses immune system and makes delay in virus elimination [58].

Mesenchymal stromal cells (MSCs) are characterized with their immunomodulatory and anti-inflammatory properties $[59,60]$. Because of these characteristics, they have been used for the treatment of various inflammatory and autoimmune disorders including diabetes, graft-versus-host disease (GvHD), and multiple sclerosis [59]. It is proven that MSCs and MSC extracellular vesicle (EV) infusion have beneficial effects in the treatment of virus-induced pneumonia by reducing the lung inflammation [61, 62]. EVs are stable, could distribute to the lungs, and have the same immunomodulatory and anti-inflammatory properties of parental MSCs [63]. MSCs decreased inflammatory cytokines and chemokines in animal model of avian influenza. They could also prevent immune cell infiltration into the lungs and improved alveolar injury [61]. Recently, there are studies evaluating allogenic MSCs and MSC-derived exosomes as potential therapeutic tools for reducing inflammation and improving COVID-19related ARDS [47, 64]. It is indicated that adoptive transfer of allogenic umbilical cord mesenchymal stem cells (UC-MSCs) could inhibit inflammation and attenuate symptoms in patients with advanced COVID-19. Four days after cell therapy, patients are disconnected from the ventilator. UC-MSC therapy also elevated $\mathrm{T}$ cell numbers and boosted the immune system [58]. Administration of ACE negative MSCs to seven COVID-19 patients improved clinical symptoms with no side effects just 2 days after injection. The number of inflammatory cytokine secreting cells reduced significantly. Regulatory DC subpopulation $\left(\mathrm{CD} 14+\mathrm{CD} 11 \mathrm{c}+\mathrm{CD} 11 \mathrm{~b}^{\mathrm{mid}}\right)$ elevated. The levels of IL-10 anti-inflammatory cytokine increased while TNF- $\alpha$ decreased [65]. Infusion of MSCs also induced lung tissue regeneration by modulating inflammatory microenvironment in COVID-19 patients [66]. There are several ongoing clinical trials using different sources of MSCs for the treatment of COVID-19 (Table 1). Taken together, MSC therapy could inhibit excessive immune system reaction, modulate inflammatory milieu, and prevent virus-mediated cytokine storm [65]. It seems that MSC therapy could be a novel therapeutic approach for the treatment of COVID-19 [64].

\section{Nanomedicine}

LIF (leukemia inhibitory factor) is one of the important cytokines to protect the respiratory system and promote lung homeostasis during viral infections $[67,68]$. This cytokine modulates severe adverse events during ARDS [67]. Up to now, there is no study investigating the role of LIF in SARS-CoV-2 infection. However, in respiratory syncytial virus (RSV) mod$\mathrm{el}$, it has been shown that overexpression of LIF enhanced the recovery of lungs during pneumonia. Neutralization of the LIF induced alveolar damage and chemokine secretion [69]. According to these data, LIF might also have protective effects in SARS-CoV-2 infection.

LIF nanoparticles (LIF-NPs) indicated clinical benefits in experimental autoimmune encephalomyelitis (EAE) animal models. LIF-NPs possessed immunomodulatory effects and increased self-tolerance in animal models for ARDS [70]. 
These inhalable NPs could be a novel strategy for lung tissue repair and cytokine storm inhibition [64]. Activation and polarization of macrophages play a major role in the initiation and intensity of inflammation, respectively, in ALI/ARDS. Peptide-coated gold nanoparticles could alleviate lung inflammation through inducing M1-to-M2 macrophage phenotype transition and increasing the anti-inflammatory cytokine (IL10 ) in the lung of acute lung injury (ALI) mice [71].

\section{Decoy biomolecules}

As mentioned above, SARS-COV-2 attaches to ACE2 receptor to invade the host cells, particularly alveolar epithelial cells. SARS-CoV-2 spike protein has strong affinity to ACE2 receptor [72-74]. This attachment may enhance viral entry and replication $[74,75]$. It is assumed that targeting this interaction and using soluble form of ACE2 could be a potential therapeutic approach [76]. Studies on COVID-19 indicated that ACE2 injection could competitively neutralize the virus and improve lung injury [77]. Recently, a novel therapeutic approach was developed based on soluble ACE2 interaction with the virus. It has been shown that human recombinant soluble ACE2 (hrsACE2) could inhibit SARS-CoV-2 from entering the host cells, decreasing the viral load in a dosedependent manner. This molecule inhibits viral infection of human blood vessels and kidney organoids. These data indicated that hrsACE2 was effective in early-stage patients [78]. Since the inhibitory effects of hrsACE2 were not complete, it is preliminarily considered that the virus may use a second receptor or co-factor such as transmembrane protease serine 2 (TMPRSS2) [79]. In this regard, TMPRSS2 inhibitor was approved for clinical application in COVID-19 to inhibit the entry of virus [74].

\section{Antiviral drugs}

Remdesivir is claimed to be an option to treat COVID-19 [80]. It is a nucleoside analog and has broad-spectrum activities against RNA viruses such as MERS; remdesivir can effectively diminish the viral load in lung tissue infected with MERS$\mathrm{CoV}$ and improve lung function in animal model [81]. The in vitro study revealed that, compared with ribavirin or favipiravir, remdesivir in combination with emetine showed the inhibition in viral yield that might achieve 64.9\% [82]. Regarding its clinical application, Grein et al. reported the good improvement among severe COVID-19 cases (68\%, $n$ = 53) after treatment with remdesivir [83]. It also showed promising results in the treatment of a patient with COVID19 in the USA [84]. However, its efficacy is doubted because, e.g., in a randomized, double-blind, placebo-controlled, multicenter trial, Wang et al. reported no statistically significant clinical benefits [85].
Chloroquine is a drug used to treat malaria [86]. It is taught that chloroquine has a great potential to treat COVID-19 [87]; chloroquine can prevent $\mathrm{pH}$-dependent steps of the replication of several viruses such as SARS-CoV [88]. Additionally, chloroquine has immunomodulatory effects by suppressing the production/release of TNF- $\alpha$ and IL- 6 . It also might interfere with viral infection and replication, as an autophagy inhibitor [89]. In preprinted paper, Chen et al. showed that hydroxychloroquine use can shorten the time to clinical recovery in COVID-19 patients [90]. Gautret et al. claimed that the treatment of COVID-19 patients with hydroxychloroquine (chloroquine analog) caused the significant viral load reduction/disappearance [91]. However, other researchers did not reveal the same effect. Moreover, high-dose chloroquine diphosphate in combination with azithromycin or oseltamivir resulted in high rates of death and adverse cardiac events [92]. Clinicians also cautioned that the increased consumption of chloroquine and hydroxychloroquine can lead to their shortage that might create a problem for people suffering systemic lupus erythematosus, other rheumatological disorders, primary Sjögren syndrome, dermatological diseases, and antiphospholipid syndrome [93].

It has been previously reported that the protease inhibitors such as lopinavir and ritonavir, used to treat infection with human immunodeficiency virus (HIV) [94], could improve the outcome of MERS-CoV- [95] and SARS$\mathrm{CoV}$ [96]-infected patients. Initially, lopinavir and ritonavir were hypothesized to inhibit the 3-chymotrypsin-like protease of SARS and MERS, and seemed to be associated with improved outcomes of patients with SARS in a non-randomized open-label trial. In a case report from Korea, it has been shown that the viral loads of a SARS-CoV-2 significantly decreased after lopinavir/ ritonavir treatment [97]. However, it is controversial whether HIV protease inhibitors could effectively inhibit the 3-chymotrypsin-like and papain-like proteases of SARS-CoV-2. HIV protease belongs to the aspartic protease family, whereas the two coronavirus proteases are from the cysteine protease family. Moreover, HIV protease inhibitors were specifically optimized to fit the $\mathrm{C} 2$ symmetry in the catalytic site of the HIV protease dimer; however, this C2-symmetric pocket is absent in coronavirus proteases. If HIV protease inhibitors alter host pathways to indirectly interfere with coronavirus infections, their potency remains a concern [98].

Favipiravir is a new type of RNA-dependent RNA polymerase inhibitor. Additionally, it is capable of blocking the replication of other RNA viruses [99]. Favipiravir is converted into an active phosphoribosylated form (favipiravir-RTP) in cells and is recognized as a substrate by viral RNA polymerase, therefore inhibiting RNA polymerase activity [100]. Favipiravir may have potential antiviral action on SARS$\mathrm{CoV}-2$, which is a RNA virus. In a clinical trial on favipiravir 
for the treatment of COVID-19, the preliminary results indicated that favipiravir had more potent antiviral action than lopinavir/ritonavir [101].

\section{BCG vaccine}

Bacillus Calmette-Guérin (BCG; weakened strain of Mycobacterium bovis) vaccination could have protective effects against COVID-19 infection. There are several mechanisms that ensure BCG-induced non-specific protection and are actively studied. BCG and viral antigens have similar molecular structure; so after vaccination, $\mathrm{B}$ and $\mathrm{T}$ cells can recognize both pathogen types. Moreover, BCG vaccination results in the so-called trained immunity-epigenetic reprogramming of innate immune cell types [102]. Monocytes of vaccinated individuals had higher expression of different surface markers of activation and synthesis of cytokines (IL-1 $\beta$, IL-6, IFN $\gamma$, and TNF) in response to infection than those of non-vaccinated ones; so nonmycobacterium pathogens, e.g., staphylococci, yellow fever virus, and influenza, can be removed faster [103]. In several preprints, it is claimed that $\mathrm{BCG}$ vaccination program could reduce the number of SARS-CoV-2-infected individuals and their mortality $[104,105]$. However, the WHO does not recommend BCG vaccination to prevent COVID-19 because there is still no direct evidence that it can protect against SARS-CoV-2 infection, and all related clinical trials are ongoing [106].

\section{Corticosteroids}

Corticosteroids are well-known with their immunosuppressive activity, which are essential to stop or delay the progression of the pneumonia and have been proved to be beneficial for the treatment of ARDS [107]. Additionally, corticosteroids have an anti-inflammatory effect to diminish systemic inflammation, reduce exudative fluid in the lung tissue, and inhibit further diffused alveolar damage, which can relieve hypoxemia which can protect the lungs effectively and prevent further progression of respiratory insufficiency [108]. The use of corticosteroids for the treatment of COVID-19 is controversial due to their negative impact on anti-viral immune responses [109]. However, it has been shown that corticosteroids could improve mortality in severe COVID-19 patients with systemic hyperinflammation [110]. It is supposed that patient selection, half-life, formulation, and dosage of the corticosteroids are important factors determining the clinical outcome. In this regard, a preprinted study indicated that in severe COVID19 patients with ARDS early short-term and low dose of corticosteroid (methylprednisolone) improved clinical manifestation and long lesions [111].

\section{Conclusion}

Although it seems that antiviral drugs are effective in improving clinical manifestation and controlling the SARS-CoV-2 infection, until now, there is no definite treatment protocol for this novel virus infection. Lymphocytopenia alongside with excessive inflammation and cytokine storm followed by ARDS in these patients are still unsolved problems that cause severity of the disease [14]. Therefore, it is considered that immune response modulation and inflammation management are essential steps. Based on the abovementioned, more studies needed to be conducted on immunopathogenesis and immune response during the SARS-CoV-2 infection. In this regard, new therapeutic approaches including mesenchymal stromal cell therapy and immune cell therapy showed promising results.

\section{Compliance with ethical standards}

Conflict of interest The authors declare that they have no conflict of interest.

\section{References}

1. Zhang L, Liu Y (2020) Potential interventions for novel coronavirus in China: a systematic review. J Med Virol

2. Wang S et al (2020) Coronaviruses and the associated potential therapeutics for the viral infections. J Infect Dis Ther 8(417):2

3. Shanmugaraj B, Malla A, Phoolcharoen W (2020) Emergence of novel coronavirus 2019-nCoV: need for rapid vaccine and biologics development. Pathogens 9(2):148

4. Li G, Fan Y, Lai Y, Han T, Li Z, Zhou P, Pan P, Wang W, Hu D, Liu X, Zhang Q, Wu J (2020) Coronavirus infections and immune responses. J Med Virol 92(4):424-432

5. Cai Q, Yang M, Liu D, Chen J, Shu D, Xia J, Liao X, Gu Y, Cai Q, Yang Y, Shen C, Li X, Peng L, Huang D, Zhang J, Zhang S, Wang F, Liu J, Chen L, Chen S, Wang Z, Zhang Z, Cao R, Zhong W, Liu Y, Liu L (2020) Experimental treatment with favipiravir for COVID-19: an open-label control study. Engineering

6. Thiel V, Weber F (2008) Interferon and cytokine responses to SARS-coronavirus infection. Cytokine Growth Factor Rev 19(2):121-132

7. Wang D et al (2020) Clinical characteristics of 138 hospitalized patients with 2019 novel coronavirus-infected pneumonia in Wuhan, China. Jama

8. Heymann DL, Shindo N (2020) COVID-19: what is next for public health? Lancet 395(10224):542-545

9. $\mathrm{Yu} \mathrm{F}$ et al (2020) Measures for diagnosing and treating infections by a novel coronavirus responsible for a pneumonia outbreak originating in Wuhan, China. Microbes Infect

10. Yan R et al (2020) Structural basis for the recognition of the SARS-CoV-2 by full-length human ACE2. Science

11. Zhu R-F et al Systematic review of the registered clinical trials of coronavirus diseases 2019 (COVID-19). medRxiv:2020

12. Frieman M, Heise M, Baric R (2008) SARS coronavirus and innate immunity. Virus Res 133(1):101-112

13. Liu L, Wei Q, Nishiura K, Peng J, Wang H, Midkiff C, Alvarez X, Qin C, Lackner A, Chen Z (2016) Spatiotemporal interplay of 
severe acute respiratory syndrome coronavirus and respiratory mucosal cells drives viral dissemination in rhesus macaques. Mucosal Immunol 9(4):1089-1101

14. Zhang W, Zhao Y, Zhang F, Wang Q, Li T, Liu Z, Wang J, Qin Y, Zhang X, Yan X, Zeng X, Zhang S (2020) The use of antiinflammatory drugs in the treatment of people with severe coronavirus disease 2019 (COVID-19): the experience of clinical immunologists from China. Clin Immunol 214:108393

15. Janice Oh H-L, Ken-En Gan S, Bertoletti A, Tan YJ (2012) Understanding the $\mathrm{T}$ cell immune response in SARS coronavirus infection. Emerg Microbes Infect 1(1):1-6

16. Ng O-W, Chia A, Tan AT, Jadi RS, Leong HN, Bertoletti A, Tan YJ (2016) Memory T cell responses targeting the SARS coronavirus persist up to 11 years post-infection. Vaccine 34(17):20082014

17. Liu WJ, Lan J, Liu K, Deng Y, Yao Y, Wu S, Chen H, Bao L, Zhang H, Zhao M, Wang Q, Han L, Chai Y, Qi J, Zhao J, Meng S, Qin C, Gao GF, Tan W (2017) Protective T cell responses featured by concordant recognition of Middle East respiratory syndrome coronavirus-derived CD8+ T cell epitopes and host MHC. J Immunol 198(2):873-882

18. Liu WJ, Zhao M, Liu K, Xu K, Wong G, Tan W, Gao GF (2017) T-cell immunity of SARS-CoV: implications for vaccine development against MERS-CoV. Antivir Res 137:82-92

19. Diao B et al (2020) Reduction and functional exhaustion of $\mathrm{T}$ cells in patients with coronavirus disease 2019 (COVID-19). medRxiv

20. McLane LM, Abdel-Hakeem MS, Wherry EJ (2019) CD8 T cell exhaustion during chronic viral infection and cancer. Annu Rev Immunol 37:457-495

21. Huang C, Wang Y, Li X, Ren L, Zhao J, Hu Y, Zhang L, Fan G, Xu J, Gu X, Cheng Z, Yu T, Xia J, Wei Y, Wu W, Xie X, Yin W, Li H, Liu M, Xiao Y, Gao H, Guo L, Xie J, Wang G, Jiang R, Gao Z, Jin Q, Wang J, Cao B (2020) Clinical features of patients infected with 2019 novel coronavirus in Wuhan, China. Lancet 395(10223):497-506

22. Zheng M et al (2020) Functional exhaustion of antiviral lymphocytes in COVID-19 patients. Cell Mol Immunol:1-3

23. Zhou Y et al (2020) Aberrant pathogenic GM-CSF+ T cells and inflammatory CD14+ CD16+ monocytes in severe pulmonary syndrome patients of a new coronavirus. bioRxiv

24. Vetter P, Eckerle I, Kaiser L (2020) Covid-19: a puzzle with many missing pieces. British Medical Journal Publishing Group

25. Casadevall A, Pirofski L-a (2020) The convalescent sera option for containing COVID-19. J Clin Invest 130(4)

26. Wu X-X, Gao HN, Wu HB, Peng XM, Ou HL, Li LJ (2015) Successful treatment of avian-origin influenza A (H7N9) infection using convalescent plasma. Int J Infect Dis 41:3-5

27. Beigel JH, Voell J, Kumar P, Raviprakash K, Wu H, Jiao JA, Sullivan E, Luke T, Davey RT Jr (2018) Safety and tolerability of a novel, polyclonal human anti-MERS coronavirus antibody produced from transchromosomic cattle: a phase 1 randomised, double-blind, single-dose-escalation study. Lancet Infect Dis 18(4):410-418

28. Arabi Y et al (2015) Feasibility, safety, clinical, and laboratory effects of convalescent plasma therapy for patients with Middle East respiratory syndrome coronavirus infection: a study protocol. Springerplus 4(1):1-8

29. van Doremalen N, Falzarano D, Ying T, de Wit E, Bushmaker T, Feldmann F, Okumura A, Wang Y, Scott DP, Hanley PW, Feldmann H, Dimitrov DS, Munster VJ (2017) Efficacy of antibody-based therapies against Middle East respiratory syndrome coronavirus (MERS-CoV) in common marmosets. Antivir Res 143:30-37

30. Zhou G, Zhao Q (2020) Perspectives on therapeutic neutralizing antibodies against the novel coronavirus SARS-CoV-2. Int J Biol Sci 16(10):1718-1723
31. Duan K, Liu B, Li C, Zhang H, Yu T, Qu J, Zhou M, Chen L, Meng S, Hu Y, Peng C, Yuan M, Huang J, Wang Z, Yu J, Gao X, Wang D, Yu X, Li L, Zhang J, Wu X, Li B, Xu Y, Chen W, Peng Y, Hu Y, Lin L, Liu X, Huang S, Zhou Z, Zhang L, Wang Y, Zhang Z, Deng K, Xia Z, Gong Q, Zhang W, Zheng X, Liu Y, Yang H, Zhou D, Yu D, Hou J, Shi Z, Chen S, Chen Z, Zhang X, Yang X (2020) Effectiveness of convalescent plasma therapy in severe COVID-19 patients. Proc Natl Acad Sci 117(17):9490 9496

32. Tiberghien P, Lamballerie X, Morel P, Gallian P, Lacombe K, Yazdanpanah Y (2020) Collecting and evaluating convalescent plasma for COVID-19 treatment: why and how. Vox Sang

33. Wang S-F, Tseng SP, Yen CH, Yang JY, Tsao CH, Shen CW, Chen KH, Liu FT, Liu WT, Chen YMA, Huang JC (2014) Antibody-dependent SARS coronavirus infection is mediated by antibodies against spike proteins. Biochem Biophys Res Commun 451(2):208-214

34. Zand $\mathrm{M}$ and $\mathrm{J}$ Wang Potential mechanisms of age related severity of COVID-19 infection: implications for vaccine development and convalescent serum therapy. 2020.

35. Bakker AB et al (2005) Novel human monoclonal antibody combination effectively neutralizing natural rabies virus variants and individual in vitro escape mutants. J Virol 79(14):9062-9068

36. Sneller MC et al (2019) An open-label phase 1 clinical trial of the anti- $\alpha 4 \beta 7$ monoclonal antibody vedolizumab in HIV-infected individuals. Sci Transl Med 11(509):eaax3447

37. Jin Y, Lei C, Hu D, Dimitrov DS, Ying T (2017) Human monoclonal antibodies as candidate therapeutics against emerging viruses. Front Med 11(4):462-470

38. Corti D, Passini N, Lanzavecchia A, Zambon M (2016) Rapid generation of a human monoclonal antibody to combat Middle East respiratory syndrome. J Infect Public Health 9(3):231-235

39. Zhu Z, Chakraborti S, He Y, Roberts A, Sheahan T, Xiao X, Hensley LE, Prabakaran P, Rockx B, Sidorov IA, Corti D, Vogel L, Feng Y, Kim JO, Wang LF, Baric R, Lanzavecchia A, Curtis KM, Nabel GJ, Subbarao K, Jiang S, Dimitrov DS (2007) Potent cross-reactive neutralization of SARS coronavirus isolates by human monoclonal antibodies. Proc Natl Acad Sci 104(29): 12123-12128

40. Sui J, Li W, Murakami A, Tamin A, Matthews LJ, Wong SK, Moore MJ, Tallarico ASC, Olurinde M, Choe H, Anderson LJ, Bellini WJ, Farzan M, Marasco WA (2004) Potent neutralization of severe acute respiratory syndrome (SARS) coronavirus by a human $\mathrm{mAb}$ to $\mathrm{S} 1$ protein that blocks receptor association. Proc Natl Acad Sci 101(8):2536-2541

41. Traggiai E, Becker S, Subbarao K, Kolesnikova L, Uematsu Y, Gismondo MR, Murphy BR, Rappuoli R, Lanzavecchia A (2004) An efficient method to make human monoclonal antibodies from memory B cells: potent neutralization of SARS coronavirus. Nat Med 10(8):871-875

42. Corti D, Zhao J, Pedotti M, Simonelli L, Agnihothram S, Fett C, Fernandez-Rodriguez B, Foglierini M, Agatic G, Vanzetta F, Gopal R, Langrish CJ, Barrett NA, Sallusto F, Baric RS, Varani L, Zambon M, Perlman S, Lanzavecchia A (2015) Prophylactic and postexposure efficacy of a potent human monoclonal antibody against MERS coronavirus. Proc Natl Acad Sci 112(33):1047310478

43. Luke $\mathrm{T}$ et al (2016) Human polyclonal immunoglobulin $\mathrm{G}$ from transchromosomic bovines inhibits MERS-CoV in vivo. Sci Transl Med 8(326):326ra21-326ra21

44. Johnson RF, Bagci U, Keith L, Tang X, Mollura DJ, Zeitlin L, Qin J, Huzella L, Bartos CJ, Bohorova N, Bohorov O, Goodman C, Kim DH, Paulty MH, Velasco J, Whaley KJ, Johnson JC, Pettitt J, Ork BL, Solomon J, Oberlander N, Zhu Q, Sun J, Holbrook MR, Olinger GG, Baric RS, Hensley LE, Jahrling PB, Marasco WA (2016) 3B11-N, a monoclonal antibody against MERS-CoV, 
reduces lung pathology in rhesus monkeys following intratracheal inoculation of MERS-CoV Jordan-n3/2012. Virology 490:49-58

45. Chen W-H, PJ Hotez, and ME Bottazzi Potential for developing the SARS-CoV receptor binding domain recombinant protein (RBD) as a heterologous human vaccine for SARS-CoV-2. 2020

46. Zheng $\mathrm{Z}$ et al (2020) Monoclonal antibodies for the $\mathrm{S} 2$ subunit of spike of SARS-CoV cross-react with the newly-emerged SARSCoV-2. bioRxiv

47. Zumla A, Hui DS, Azhar EI, Memish ZA, Maeurer M (2020) Reducing mortality from 2019-nCoV: host-directed therapies should be an option. Lancet 395(10224):e35-e36

48. Xu X et al (2020) Effective treatment of severe COVID-19 patients with tocilizumab, in China. Xiv:20200300026

49. Chiappelli F, Khakshooy A, Greenberg G (2020) CoViD-19 Immunopathology \& Immunotherapy. Bioinformation 16(3): 219-222

50. Richardson P, Griffin I, Tucker C, Smith D, Oechsle O, Phelan A, Stebbing J (2020) Baricitinib as potential treatment for 2019nCoV acute respiratory disease. Lancet 395(10223):e30-e31

51. Stebbing J, Phelan A, Griffin I, Tucker C, Oechsle O, Smith D, Richardson P (2020) COVID-19: combining antiviral and antiinflammatory treatments. Lancet Infect Dis 20:400-402

52. Wang F, Nie J, Wang H, Zhao Q, Xiong Y, Deng L, Song S, Ma Z, Mo P, Zhang Y (2020) Characteristics of peripheral lymphocyte subset alteration in COVID-19 pneumonia. J Infect Dis 221: 1762-1769

53. Liu Z, Long W, Tu M, Chen S, Huang Y, Wang S, Zhou W, Chen D, Zhou L, Wang M, Wu M, Huang Q, Xu H, Zeng W, Guo L (2020) Lymphocyte subset (CD4+, CD8+) counts reflect the severity of infection and predict the clinical outcomes in patients with COVID-19. J Infect

54. Madera S, Rapp M, Firth MA, Beilke JN, Lanier LL, Sun JC (2016) Type I IFN promotes NK cell expansion during viral infection by protecting NK cells against fratricide. J Exp Med 213(2):225-233

55. Shi Y et al (2020) Immunopathological characteristics of coronavirus disease 2019 cases in Guangzhou, China. medRxiv

56. Wan S et al (2020) Characteristics of lymphocyte subsets and cytokines in peripheral blood of 123 hospitalized patients with 2019 novel coronavirus pneumonia (NCP). Medrxiv

57. Weiskopf D et al (2020) Phenotype of SARS-CoV-2-specific Tcells in COVID-19 patients with acute respiratory distress syndrome. medRxiv

58. Liang B et al Clinical remission of a critically ill COVID-19 patient treated by human umbilical cord mesenchymal stem cells

59. Hashemi SM et al (2019) Investigating the route of administration and efficacy of adipose tissue-derived mesenchymal stem cells and conditioned medium in type 1 diabetic mice. Inflammopharmacology:1-17

60. Hossein-Khannazer N et al (2019) Study of the immunomodulatory effects of osteogenic differentiated human dental pulp stem cells. Life Sci 216:111-118

61. Li Y, Xu J, Shi W, Chen C, Shao Y, Zhu L, Lu W, Han XD (2016) Mesenchymal stromal cell treatment prevents H9N2 avian influenza virus-induced acute lung injury in mice. Stem Cell Res Ther 7(1):159

62. Khatri M, Richardson LA, Meulia T (2018) Mesenchymal stem cell-derived extracellular vesicles attenuate influenza virusinduced acute lung injury in a pig model. Stem Cell Res Ther 9(1):1-13

63. Bari E, Ferrarotti I, Saracino L, Perteghella S, Torre ML, Corsico AG (2020) Mesenchymal stromal cell secretome for severe COVID-19 infections: premises for the therapeutic use. Cells 9(4):924

64. Metcalfe SM (2020) Mesenchymal stem cells and management of COVID-19 pneumonia. Med Drug Discov 5:100019
65. Leng Z, Zhu R, Hou W, Feng Y, Yang Y, Han Q, Shan G, Meng F, du D, Wang S, Fan J, Wang W, Deng L, Shi H, Li H, Hu Z, Zhang F, Gao J, Liu H, Li X, Zhao Y, Yin K, He X, Gao Z, Wang Y, Yang B, Jin R, Stambler I, Lim LW, Su H, Moskalev A, Cano A, Chakrabarti S, Min KJ, Ellison-Hughes G, Caruso C, Jin K, Zhao RC (2020) Transplantation of ACE2-mesenchymal stem cells improves the outcome of patients with COVID-19 pneumonia. Aging Dis 11(2):216-228

66. Shetty AK (2020) Mesenchymal stem cell infusion shows promise for combating coronavirus (COVID-19)-induced pneumonia. Aging Dis 11(2):462-464

67. Foronjy RF, Dabo AJ, Cummins N, Geraghty P (2014) Leukemia inhibitory factor protects the lung during respiratory syncytial viral infection. BMC Immunol 15(1):41

68. Traber KE et al (2017) Myeloid-epithelial cross talk coordinates synthesis of the tissue-protective cytokine leukemia inhibitory factor during pneumonia. Am J Phys Lung Cell Mol Phys 313(3): L548-L558

69. Poon J, Campos M, Foronjy RF, Nath S, Gupta G, Railwah C, Dabo AJ, Baumlin N, Salathe M, Geraghty P (2019) Cigarette smoke exposure reduces leukemia inhibitory factor levels during respiratory syncytial viral infection. Int J Chronic Obstruct Pulmonary Dis 14:1305-1315

70. Metcalfe SM et al (2015) Multiple sclerosis and the LIF/IL-6 axis: use of nanotechnology to harness the tolerogenic and reparative properties of LIF. Nanobiomedicine 2(Godište 2015):2-5

71. Wang L et al (2020) Manipulation of macrophage polarization by peptide-coated gold nanoparticles and its protective effects on acute lung injury. J Nanobiotechnol 18(1):1-16

72. Tolouian $\mathrm{R}$ et al (2020) COVID-19 interactions with angiotensinconverting enzyme 2 (ACE2) and the kinin system; looking at a potential treatment. J Renal Injury Prevent 9(2)

73. Cheng H, Wang Y, Wang GQ (2020) Organ-protective effect of angiotensin-converting enzyme 2 and its effect on the prognosis of COVID-19. J Med Virol

74. Hoffmann M, Kleine-Weber H, Schroeder S, Krüger N, Herrler T, Erichsen S, Schiergens TS, Herrler G, Wu NH, Nitsche A, Müller MA, Drosten C, Pöhlmann S (2020) SARS-CoV-2 cell entry depends on ACE2 and TMPRSS2 and is blocked by a clinically proven protease inhibitor. Cell 181:271-280.e8

75. Ju B et al (2020) Potent human neutralizing antibodies elicited by SARS-CoV-2 infection. bioRxiv

76. Imai Y, Kuba K, Rao S, Huan Y, Guo F, Guan B, Yang P, Sarao R, Wada T, Leong-Poi H, Crackower MA, Fukamizu A, Hui CC, Hein L, Uhlig S, Slutsky AS, Jiang C, Penninger JM (2005) Angiotensin-converting enzyme 2 protects from severe acute lung failure. Nature 436(7047):112-116

77. Zhang $\mathrm{H}$ et al (2020) Angiotensin-converting enzyme 2 (ACE2) as a SARS-CoV-2 receptor: molecular mechanisms and potential therapeutic target. Intensive Care Med:1-5

78. Monteil V (2020) Inhibition of SARS-CoV-2 infections in engineered human tissues using clinical-grade soluble human ACE2. cellpress

79. Lukassen S et al (2020) SARS-CoV-2 receptor ACE2 and TMPRSS2 are predominantly expressed in a transient secretory cell type in subsegmental bronchial branches. bioRxiv

80. Al-Tawfiq JA, Al-Homoud AH, Memish ZA (2020) Remdesivir as a possible therapeutic option for the COVID-19. Travel Med Infect Dis 34:101615

81. Sheahan TP et al (2020) Comparative therapeutic efficacy of remdesivir and combination lopinavir, ritonavir, and interferon beta against MERS-CoV. Nat Commun 11(1):019-13940

82. Choy K-T, Wong AYL, Kaewpreedee P, Sia SF, Chen D, Hui KPY, Chu DKW, Chan MCW, Cheung PPH, Huang X, Peiris M, Yen HL (2020) Remdesivir, lopinavir, emetine, and 
homoharringtonine inhibit SARS-CoV-2 replication in vitro. Antivir Res 178:104786

83. Grein J, Ohmagari N, Shin D, Diaz G, Asperges E, Castagna A, Feldt T, Green G, Green ML, Lescure FX, Nicastri E, Oda R, Yo K, Quiros-Roldan E, Studemeister A, Redinski J, Ahmed S, Bernett J, Chelliah D, Chen D, Chihara S, Cohen SH, Cunningham J, D'Arminio Monforte A, Ismail S, Kato H, Lapadula G, L'Her E, Maeno T, Majumder S, Massari M, MoraRillo M, Mutoh Y, Nguyen D, Verweij E, Zoufaly A, Osinusi AO, DeZure A, Zhao Y, Zhong L, Chokkalingam A, Elboudwarej E, Telep L, Timbs L, Henne I, Sellers S, Cao H, Tan SK, Winterbourne L, Desai P, Mera R, Gaggar A, Myers RP, Brainard DM, Childs R, Flanigan T (2020) Compassionate use of remdesivir for patients with severe Covid-19. N Engl J Med

84. Holshue ML, DeBolt C, Lindquist S, Lofy KH, Wiesman J, Bruce H, Spitters C, Ericson K, Wilkerson S, Tural A, Diaz G, Cohn A, Fox L, Patel A, Gerber SI, Kim L, Tong S, Lu X, Lindstrom S, Pallansch MA, Weldon WC, Biggs HM, Uyeki TM, Pillai SK, Washington State 2019-nCoV Case Investigation Team (2020) First case of 2019 novel coronavirus in the United States. N Engl J Med 382(10):929-936

85. Wang Y, Zhang D, du G, du R, Zhao J, Jin Y, Fu S, Gao L, Cheng Z, Lu Q, Hu Y, Luo G, Wang K, Lu Y, Li H, Wang S, Ruan S, Yang C, Mei C, Wang Y, Ding D, Wu F, Tang X, Ye X, Ye Y, Liu B, Yang J, Yin W, Wang A, Fan G, Zhou F, Liu Z, Gu X, Xu J, Shang L, Zhang Y, Cao L, Guo T, Wan Y, Qin H, Jiang Y, Jaki T, Hayden FG, Horby PW, Cao B, Wang C (2020) Remdesivir in adults with severe COVID-19: a randomised, double-blind, placebo-controlled, multicentre trial. Lancet 395:1569-1578

86. Aguiar AC et al (2018) Chloroquine analogs as antimalarial candidates with potent in vitro and in vivo activity. Int J Parasitol Drugs Drug Resist 8(3):459-464

87. Cortegiani A, Ingoglia G, Ippolito M, Giarratano A, Einav S (2020) A systematic review on the efficacy and safety of chloroquine for the treatment of COVID-19. J Crit Care 57:279-283

88. Vincent MJ et al (2005) Chloroquine is a potent inhibitor of SARS coronavirus infection and spread. Virol J 2(69):2-69

89. Golden EB, Cho HY, Hofman FM, Louie SG, Schönthal AH, Chen TC (2015) Quinoline-based antimalarial drugs: a novel class of autophagy inhibitors. Neurosurg Focus 38(3):E12

90. Chen $Z$ et al (2020) Efficacy of hydroxychloroquine in patients with COVID-19: results of a randomized clinical trial. MedRxiv

91. Gautret P, Lagier JC, Parola P, Hoang VT, Meddeb L, Mailhe M, Doudier B, Courjon J, Giordanengo V, Vieira VE, Dupont HT, Honoré S, Colson P, Chabrière E, la Scola B, Rolain JM, Brouqui P, Raoult D (2020) Hydroxychloroquine and azithromycin as a treatment of COVID-19: results of an open-label non-randomized clinical trial. Int J Antimicrob Agents: 105949

92. Borba MGS, Val FFA, Sampaio VS, Alexandre MAA, Melo GC, Brito M, Mourão MPG, Brito-Sousa JD, Baía-da-Silva D, Guerra MVF, Hajjar LA, Pinto RC, Balieiro AAS, Pacheco AGF, Santos JDO Jr, Naveca FG, Xavier MS, Siqueira AM, Schwarzbold A, Croda J, Nogueira ML, Romero GAS, Bassat Q, Fontes CJ, Albuquerque BC, Daniel-Ribeiro CT, Monteiro WM, Lacerda MVG, for the CloroCovid-19 Team (2020) Effect of high vs low doses of chloroquine diphosphate as adjunctive therapy for patients hospitalized with severe acute respiratory syndrome coronavirus 2 (SARS-CoV-2) infection: a randomized clinical trial. JAMA Netw Open 3(4):e208857-e208857

93. Jakhar D, Kaur I (2020) Potential of chloroquine and hydroxychloroquine to treat COVID-19 causes fears of shortages among people with systemic lupus erythematosus. Nat Med:1-1
94. Cvetkovic RS, Goa KL (2003) Lopinavir/ritonavir: a review of its use in the management of HIV infection. Drugs 63(8):769-802

95. Arabi YM et al (2018) Treatment of Middle East respiratory syndrome with a combination of lopinavir-ritonavir and interferon$\beta 1 \mathrm{~b}$ (MIRACLE trial): study protocol for a randomized controlled trial. Trials 19(1):81

96. Chu C, Cheng VC, Hung IF, Wong MM, Chan KH, Chan KS, Kao RY, Poon LL, Wong CL, Guan Y, Peiris JS, Yuen KY, HKU/ UCH SARS Study Group (2004) Role of lopinavir/ritonavir in the treatment of SARS: initial virological and clinical findings. Thorax 59(3):252-256

97. Lim J et al (2020) Case of the index patient who caused tertiary transmission of COVID-19 infection in Korea: the application of lopinavir/ritonavir for the treatment of COVID-19 infected pneumonia monitored by quantitative RT-PCR. J Korean Med Sci $35(6)$

98. Wu C et al (2020) Analysis of therapeutic targets for SARS-CoV2 and discovery of potential drugs by computational methods. Acta Pharm Sin B

99. Delang L, Abdelnabi R, Neyts J (2018) Favipiravir as a potential countermeasure against neglected and emerging RNA viruses. Antivir Res 153:85-94

100. Furuta Y, Komeno T, Nakamura T (2017) Favipiravir (T-705), a broad spectrum inhibitor of viral RNA polymerase. Proc Jpn Acad Series B 93(7):449-463

101. Dong L, Hu S, Gao J (2020) Discovering drugs to treat coronavirus disease 2019 (COVID-19). Drug Discov Ther 14(1):58-60

102. Goodridge HS, Ahmed SS, Curtis N, Kollmann TR, Levy O, Netea MG, Pollard AJ, van Crevel R, Wilson CB (2016) Harnessing the beneficial heterologous effects of vaccination. Nat Rev Immunol 16(6):392-400

103. Arts RJ et al (2018) BCG vaccination protects against experimental viral infection in humans through the induction of cytokines associated with trained immunity. Cell Host Microbe 23(1):89100. e5

104. Miller A et al (2020) Correlation between universal BCG vaccination policy and reduced morbidity and mortality for COVID-19: an epidemiological study. medRxiv

105. Dayal D, Gupta S (2020) Connecting BCG vaccination and COVID-19: additional data. medRxiv

106. Organization WH Bacille Calmette-Guérin (BCG) vaccination and COVID-19: scientific brief, 12 April 2020. 2020, World Health Organization

107. Thompson BT (2003) Glucocorticoids and acute lung injury. Crit Care Med 31(4):S253-S257

108. Rhen T, Cidlowski JA (2005) Antiinflammatory action of glucocorticoids - new mechanisms for old drugs. N Engl J Med 353(16):1711-1723

109. Yang X et al (2020) Clinical course and outcomes of critically ill patients with SARS-CoV-2 pneumonia in Wuhan, China: a singlecentered, retrospective, observational study. Lancet Respir Med

110. Siddiqi HK, Mehra MR (2020) COVID-19 illness in native and immunosuppressed states: a clinical-therapeutic staging proposal. J Heart Lung Transplant 39:405-407

111. Wang Y et al (2020) Early, low-dose and short-term application of corticosteroid treatment in patients with severe COVID-19 pneumonia: single-center experience from Wuhan, China. medRxiv

Publisher's note Springer Nature remains neutral with regard to jurisdictional claims in published maps and institutional affiliations. 